\title{
DAMPAK IMPLEMENTASI PERDA PERLINDUNGAN LAHAN PERTANIAN PANGAN BERKELANJUTAN (LP2B) DI PROVINSI JAWA BARAT
}

\author{
I Made Yoga Prasada, Moh. Wahyudi Priyanto \\ Program Studi Ekonomi Pertanian, Fakultas Pertanian Univeritas Gadjah Mada \\ Email: imade.yogap@gmail.com
}

\begin{abstract}
The West Java Province Government in 2010 has determined the Regional Regulation Number 27 of 2010 concerning Protection of Sustainable Food Agriculture Land (LP2B). The regulation should be applied to control the rate of conversion of agricultural land in West Java Province, so food availability and food security of the population can be increased. This research aim to determine the impact of the regional regulation implementation by comparing the area of rice field conversion and food security before and after the policy was implemented. The research data used are secondary data from the Central Bureau of Statistics of West Java Province in 2004-2009 (before the application of LP2B) and in 2010-2015 (after the application of LP2B). Data were analyzed by calculating the converted area of wetland and calculating the rice availability using paddy-rice conversion factors from BKPP and determining the level of food security. The difference before and after the implementation of the policy was tested by the Wilcoxon Test. The results showed that the conversion of agricultural land that occurred after the implementation of the policy was higher than before the implementation of the policy. However, population food security showed an increase after the conversion of wetland occurred compared to before conversion. However, the results of the Wilcoxon Test show that there are no significant differences between the area of wetland conversion and food security before and after the implementation of the policy.
\end{abstract}

Keywords: food security, LP2B, West Java, wetland conversion.

\section{PENDAHULUAN}

Peningkatan kebutuhan dan pertumbuhan jumlah penduduk akan semakin meningkat setiap tahunnya baik kebutuhan akan pangan maupun papan. Permasalahan akan terjadi apabila kebutuhan papan (perumahan, industri, perkantoran dan pusat perbelanjaan) lebih besar daripada kebutuhan pangan. Kondisi tersebut akan mengakibatkan peningkatan persaingan antara pemenuhan kedua kebutuhan tersebut, disisi lain ketersediaan lahan selalu tetap. Seiring berjalannya waktu, kebutuhan papan lebih diprioritaskan daripada kebutuhan pangan (Dwipradnyana dkk.,
2015). Ketidakmampuan lahan dalam memenuhi kedua kebutuhan tersebut secara terpaksa harus mengesampingkan satu sektor untuk sektor yang lain, yaitu dengan mengurangi jumlah lahan untuk dikembangkan menjadi sektor yang lebih diprioritaskan atau lebih dikenal dengan alih fungsi lahan atau konversi lahan (Hadiwinata et al., 2014). Sektor yang selalu dirugikan dari aktivitas tersebut adalah sektor pertanian. Anggapan bahwa luas lahan sektor pertanian lebih besar dari pada sektor non pertanian, sehingga lahan pertanian akan selalu tersedia terus menerus sehingga konversi lahan lebih 
sering terjadi pada lahan pertanian tanpa mempertimbangkan tingkat produktifitas dari lahan yang digunakan (Prasada \& Rosa, 2018). Menurut Purbiyanti dkk. (2017), luas lahan sawah yang dikonversi dalam 3 dekade terakhir mencapai 10.616,4 ha per tahun, yang terdiri dari $8.346,65$ ha per tahun di daerah Jawa dan 2.269,75 ha per tahun di luar Jawa. Sampai saat ini sebagian besar lahan pertanian yang subur dimanfaatkan untuk sektor pertanian maupun non pertanian (Industri, Infrastruktur dan pemukiman). Bahkan, lahan sawah intensif mengalami penyusutan akibat konversi lahan untuk sektor lain. Lahan yang masih tersisa untuk sektor pertanian adalah lahan suboptimal atau marginal dengan masalah kesuburan atau biofisik (Mulyani dkk., 2011).

Konversi lahan memberikan dampak jangka panjang bagi petani dan masyarakat. Menyusutnya luas lahan pertanian akan menurunkan lapangan pekerjaan untuk petani dan buruh tani serta akan menurunkan peluang untuk memperoleh pendapatan dari kegiatan usaha di lahan pertanian seperti usaha penyediaan saprodi, alsintan, penyewaan traktor, dan lain-lain. Dampak negatif juga dirasakan masyarakat karena menyusutnya jumlah lahan akan menurunkan ketersediaan pangan sehingga akan mengancam ketahanan pangan (Purwaningsih dkk., 2015). Ketahanan pangan yang dimaksud adalah pada saat pangan tersedia untuk memenuhi kebutuhan masyarakat setiap saat untuk dapat hidup sehat, aktif dan produktif. Syarat-syarat agar ketahanan pangan mampu memenuhi kebutuhan yaitu keterjangkauan, harga sesuai dengan daya beli masyarakat, memenuhi kebutuhan gizi masing-masing individu, keamanan pangan, dan selalu tersedia secara terus-menerus (Suandi, 2012). Salah satu komoditas pangan utama masyarakat Indonesia yaitu padi menjadi komoditas yang terdampak paling menghawatirkan dan paling merugikan. Komoditas tersebut yang seharusnya selalu ada dan memenuhi kebutuhan masyarakat setiap waktu, akan menyebabkan gizi buruk, kesehatan terganggu, dan menurunkan kualitas sumberdaya manusia apabila pasokan berkurang. Dampak lainnya yaitu akan menimbulkan terganggunya stabilitas politik, ekonomi, kemananan dan ketergantungan pada Negara lain atau akan melakukan Impor beras (Santosa dkk., 2011). Apabila konversi lahan yang sedang marak saat ini tidak mampu dikendalikan secara serius, maka ancaman kelangkaan konsumsi pangan komoditas padi akan semakin meningkat dan dalam jangka panjang akan menimbulkan kerugian sosial (Hadiwinata et al., 2014).

Mengingat konversi lahan menimbulkan dampak negatif, penting bagi pemerintah sebagai pembuat kebijakan untuk menekan laju konversi lahan. Salah satu langkah yang telah dilakukan adalah dengan menerbitkan Undang-Undang No. 41 tahun 2009 mengenai Perlindungan Lahan Pertanian Pangan 
Berkelanjutan (LP2B) dan direspon oleh pemerintah daerah, khususnya Pemerintah Daearah Jawa Barat dalam bentuk Perarturan Daerah Nomor 27 Tahun 2010 Tentang Perlindungan Lahan Pertanian Pangan Berkelanjutan (LP2B). Undang-Undang tersebut untuk mengatasi permasalahan degradasi, konversi dan fragmentasi lahan pertanian pangan sebagai akibat dari pertambahan jumlah penduduk, perkembangan ekonomi dan industrialisasi yang dapat mengancam kemandirian, ketahanan dan kedaulatan pangan. Pengendalian konversi lahan pertanian melibatkan peraturan dan pelakunya, sehingga antar instansi yang terlibat perlu berkontribusi dan bekerjasama secara maksimal agar konversi lahan dapat dikendalikan. Selain itu perlu adanya sosialisasi pada masyarakat mengenai pentingnya menjaga lahan pertanian demi tetap mewujudkan ketahanan pangan dan kedaulatan pangan (Anita dkk., 2012). Menurut Wang et al. (2018) Menghargai dan memanfaatkan lahan secara rasional dan dengan melindungi lahan pertanian dan ekosistem alam penting untuk mendorong kemajuan suatu negara. Tujuan dan keberlanjutan pangan nasional akan terjamin dengan mengembangkan kebijakan konversi lahan.

Telah banyak penelitian mengenai mengenai konversi lahan seperti yang telah dilakukan oleh (Prasada \& Rosa, 2018), penelitian tersebut dilakukan untuk melihat dampak konversi lahan terhadap ketahanan pangan di Daerah Istimewa Yogyakarta. Dengan topik yang sama, Yanti dkk., (2013) melakukan penelitian di Kabupaten Seluma, Bengkulu untuk mengidentifikasi faktor-faktor yang mempengaruhi konversi lahan pertanian dan melihat dampaknya bagi produksi padi. Irawan (2014) juga melakukan penelitian mengenai kebijakan Perlindungan Lahan Pertanian Pangan Berkelanjutan, tujuannya adalah untuk mengkaji implementasi kebijakan dan faktor yang berpengaruh terhadap kebijakan tersebut. Berdasarkan berbagai penelitian yang telah dilakukan, belum terdapat penelitian yang membahas dampak penerapan perda LP2B terhadap luas konversi lahan sawah dan ketahanan pangan penduduk. Oleh karena itu, penelitian ini dilakukan untuk mengetahui dampak penerapan perda tersebut terhadap luas konversi lahan sawah dan ketahanan pangan penduduk.

\section{METODE PENELITIAN}

Jenis data yang digunakan dalam penelitian ini adalah data sekunder yang diperoleh dari Badan Pusat Statistika Provinsi Jawa Barat dari tahun 2004 sampai tahun 2015. Pemilihan Provinsi Jawa Barat sebagai objek penelitian karena merupakan provinsi pertama di Jawa yang menerapkan kebijakan Lahan Pertanian Pangan Berkelanjutan (LP2B) yaitu pada tahun 2010. Peraturan Daerah Provinsi Jawa Barat Nomor 27 tahun 2010 yang dibuat didasari atas 
kekhawatiran Pemerintah Jawa Barat atas maraknya alih fungsi lahan yang terjadi akibat pertambahan jumlah penduduk, pertumbuhan ekonomi dan industri.

Data-data yang diperoleh diolah dengan menggunakan metode perhitungan dan analisis sebagai berikut:

1. Produksi padi yang hilang

Jumlah produksi padi yang hilang akibat konversi lahan diperoleh dengan menggunakan data jumlah konversi lahan sawah (ha) dan produktivitas padi (ton/ha) pada periode yang sama (Prasada \& Rosa, 2018).

\section{$\mathrm{PPH}=\mathrm{Pdvt} \times \mathrm{At}$}

Keterangan:

$\mathrm{PPH}=$ Produksi padi yang hilang (ton)

$\mathrm{Pdvt}=$ Produktivitas padi (ton/ha)

At = Luas konversi lahan sawah (ha)

\section{Ketahanan pangan (surplus/defisit)}

Data ketahanan pangan dihitung untuk mengetahui dampak kebijakan konversi lahan sawah terhadap ketersediaan pangan bagi masyarakat setiap waktu. Ketahanan pangan tercapai apabila jumlah pangan yang tersedia dapat memenuhi konsumsi masyarakat dalam suatu wilayah dan satu waktu.

\section{a. Pangan Tersedia}

Pangan tersedia adalah kuantitas komoditas padi yang khusus untuk dikonsumsi oleh masyarakat, dihitung dengan cara (Prasada \& Rosa, 2018):
- Pangan tersedia= produksi padi

bruto-faktor konversi padi

Menurut Badan Ketahanan Pangan dan Penyuluhan dalam publikasi Neraca Bahan Makanan Indonesia, faktor-faktor konversi padi yaitu padi untuk kebutuhan bibit sebesar 0,9\%, padi untuk kebutuhan pakan sebesar $0,44 \%$, padi untuk kebutuhan industri non pangan $0,56 \%$ dan padi tercecer sebesar $5,4 \%$.

b. Ketahanan Pangan

Ketahanan pangan suatu wilayah dapat dilihat dari selisih pangan tersedia dengan kebutuhan konsumsi pangan masyarakat (Darsono, 2012). Terdapat dua kategori dari hasil perhitungan ketahanan pangan, yaitu:

- Tercapai ketahanan pangan (surplus) apabila pangan tersedia lebih besar atau sama dengan kebutuhan konsumsi masyarakat

- Tidak tercapai ketahanan pangan (defisit) apabila pangan tersedia kurang dari kebutuhan konsumsi masyarakat

Nilai surplus ketahanan pangan yang semakin besar disuatu wilayah menunjukan semakin tinggi tingkat ketahanan pangan masyarakatnya. Sebaliknya, apabila semakin tinggi defisit pangan maka tingkat ketahanan pangan masyarakat di suatu wilayah semakin rendah.

\section{Uji Wilcoxon}

Wilcoxon merupakan metode analisis statistik non-parametrik yang digunakan untuk menganalisis apakah terdapat perbedaan antara hasil-hasil pengamatan berpasangan sebelum 
dan setelah diterapkan perlakuan (Tanty dkk., 2013). Syarat data yang bisa diolah dengan Wilcoxon test berupa data bertipe interval atau ratio dan datanya tidak mengikuti syarat distribusi normal. Dalam penelitian ini, Wilcoxon test digunakan untuk melihat perbedaan rataan antara kondisi luas konversi lahan sawah dan ketahanan pangan sebelum dan setelah diterapkan kebijakan.

\section{HASIL DAN PEMBAHASAN}

Disahkannya Peraturan Daerah Provinsi Jawa Barat Nomor 27 Tahun 2010 Tentang Perlindungan Lahan Pertanian Pangan Berkelanjutan (LP2B) memiliki semangat positif yang kuat untuk dapat meningkatkan ketersediaan pangan dan meningkatkan ketahanan pangan penduduk di Jawa Barat dengan jalan mengendalikan laju konversi lahan pertanian dan melakukan ekstensifikasi lahan pertanian di wilayah tersebut. Pasal 3 dalam Perda Provinsi Jawa Barat No. 27 Tahun 2010 tersebut menyatakan bahwa perlindungan lahan pertanian pangan berkelanjutan dilakukan dengan maksud untuk melakukan pembinaan, pengawasan, dan pengendalian alih fungsi lahan pertanian pangan untuk menjamin tersedianya lahan pertanian pangan secara berkelanjutan melalui pemberian insentif kepada petani dan penerapan disinsentif bagi pihak yang melakukan alih fungsi lahan pertanian pangan. Selain itu, pada pasal 19 juga disebutkan bahwa penerapan Perda No. 27 Tahun 2010 diterapkan juga untuk menjadi dasar hukum yang kuat bagi pemerintah dalam upaya melakukan pengembangan kawasan pertanian pangan berkelanjutan di daerah dengan cara melakukan intensifikasi atau ekstensifikasi lahan pertanian. Pada perda tersebut sangat jelas bahwa semangat pembuatan dan penerapan perda ini adalah untuk mencegah atau mengendalikan konversi lahan pertanian di Jawa Barat dan untuk melakukan pengembangan kawasan pertanian pangan berkelanjutan dengan penerapan intensifikasi dan ekstensifikasi lahan pertanian. Oleh karena itu, penerapan Perda No. 27 Tahun 2010 diharapkan dapat membantu mencegah alih fungsi lahan di Jawa Barat dan mampu menjadi dasar hukum yang kuat untuk meningkatkan luas lahan pertanian di Jawa Barat. Akan tetapi, pada pelaksanaannya penerapan perda tersebut nampaknya belum sepenuhnya dapat berjalan dengan baik sesuai maksud dan tujuan yang diharapkan. Hal ini dapat terlihat dari dinamika perkembangan luas lahan pertanian, khususnya lahan sawah di Jawa Barat yang cenderung mengalami penurunan yang menandakan telah terjadinya alih fungsi lahan sawah yang relatif besar dibandingkan dengan pembukaan lahan sawah baru walaupun perda tersebut telah disahkan pada tahun 2010. Dinamika perkembangan luas lahan sawah di Jawa Barat dapat dilihat pada tabel 1 berikut ini. 
Tabel 1. Dinamika Perkembangan Luas Lahan Sawah di Jawa Barat

\begin{tabular}{|c|c|c|c|c|}
\hline Tahun & $\begin{array}{l}\text { Luas Lahan } \\
\text { Sawah (ha) }\end{array}$ & $\begin{array}{r}\text { Luas Alih } \\
\text { Fungsi Lahan } \\
\text { Sawah (ha) }\end{array}$ & $\begin{array}{r}\text { Luas } \\
\text { Pembukaan } \\
\text { Lahan Sawah } \\
\text { (ha) }\end{array}$ & $\begin{array}{r}\text { Laju Penyusutan } \\
\text { Luas Lahan Sawah } \\
(\%)\end{array}$ \\
\hline 2004 & 932.337 & 0 & 0 & 0,00 \\
\hline 2005 & 925.900 & 6.4 & 0 & $-0,69$ \\
\hline 2006 & 926.782 & 0 & 882 & 0,10 \\
\hline 2007 & 934.845 & 0 & 8.0 & 0,87 \\
\hline 2008 & 945.544 & 0 & 10.6 & 1,14 \\
\hline 2009 & 937.373 & 8.1 & 0 & $-0,86$ \\
\hline 2010 & 930.268 & 7.1 & 0 & $-0,76$ \\
\hline 2011 & 930.507 & 0 & 239 & 0,03 \\
\hline 2012 & 923.575 & 6.9 & 0 & $-0,74$ \\
\hline 2013 & 925.042 & 0 & 1.467 & 0,16 \\
\hline 2014 & 924.307 & 735 & 0 & $-0,08$ \\
\hline 2015 & 912.794 & 11.513 & 0 & $-1,25$ \\
\hline Total & $1.114 .9274,00$ & $34.456,00$ & $21.350,00$ & $-1,40$ \\
\hline Rata-rata & $99.547,09$ & $3.445,60$ & $2.135,00$ & $-0,14$ \\
\hline
\end{tabular}

Sumber: BPS Jawa Barat, 2016

Berdasarkan tabel 1 dapat diketahui bahwa rata-rata alih fungsi lahan sawah yang terjadi di Jawa Barat pada periode tahun 2004 hingga tahun 2015 rata-rata sebesar 3.445,60 hektar per tahun. Nilai tersebut jauh lebih besar dibandingkan dengan luas pembukaan lahan yang dilakukan oleh pemerintah daerah yang hanya mampu mencetak lahan sawah baru rata-rata sebesar 2.135,00 hektar per tahun. Tingginya luas lahan sawah yang teralihfungsikan dibandingkan dengan luas lahan sawah yang tercetak dapat menimbulkan dampak negatif terhadap menurunnya potensi hasil produksi beras yang dapat dihasilkan (Daulay et al., 2016). Menurunnya potensi produksi beras tentu akan berdampak pula terhadap menurunnya ketersediaan beras untuk konsumsi penduduk (Yasar \& Siwar, 2016), sehingga dapat memicu turunnya tingkat ketahanan pangan (Aragie \& Genanu, 2017). Selanjutnya, data pada tabel 1 dapat disusun kembali untuk mengetahui besarnya alih fungsi lahan sawah sebelum dan setelah perda LP2B diterapkan. Besarnya luas alih fungsi lahan sawah sebelum dan setelah penerapan perda LP2B dapat dilihat pada tabel 2 berikut ini.

Tabel 2 menunjukkan data konversi lahan sawah yang terjadi di Jawa Barat sebelum dan setelah penerapan perda LP2B. Perda LP2B mulai disahkan dan secara resmi dilaksanakan sejak tahun 2010. Oleh karena itu, periode data dapat dipisahkan menjadi dua periode yang berbeda, yaitu periode sebelum perda dilaksanakan (2004-2009) dan setelah perda dilaksanakan (2010-2015).

Berdasarkan tabel 2 dapat diketahui bahwa rerata luas lahan sawah yang dikonversikan 
sebelum perda diterapkan adalah sebesar 2.434,67 hektar per tahun. Nilai tersebut relatif lebih kecil jika dibandingkan dengan periode setalah perda diterapkan yang memiliki rerata luas lahan sawah yang dikonversikan sebesar 4.380,83 hektar per tahun. Luas alih fungsi lahan sawah di Jawa Barat lebih besar terjadi pada periode waktu setelah penerapan perda dibandingkan dengan periode sebelum penerapan perda. Hal ini menggambarkan bahwa penerapan perda LP2B di Jawa Barat belum dapat dijalankan sesuai dengan semangat, tujuan, dan cita-cita pembuatan dan implementasi dari perda tersebut, sehingga implementasi dari perda LP2B belum mampu memberikan dampak positif terhadap peningkatan luas lahan pertanian pangan di Provinsi Jawa Barat. Keiky (2016) menjelaskan bahwa perda perlindungan lahan pertanian pangan berkelanjutan merupakan peraturan yang sangat penting untuk dapat diimplementasikan dengan baik, sebab menyangkut kegiatan produksi tanaman pangan yang penting untuk memenuhi kebutuhan pangan penduduk. Akan tetapi, dalam pelaksanaannya sering terjadi ketidakefektifan implementasi peraturan perundang-undangan akibat masih belum jelasnya objek lahan pertanian yang dilindungi, dan kurangnya pengetahuan dan kesadaran masyarakat tentang pentingnya perlindungan lahan pertanian pangan (Irawan, 2014; Rachmanto, 2014).

Luas konversi lahan sawah di Jawa Barat kemudian dapat dianalisis secara statistik dengan menggunakan Uji Wilcoxon untuk mengetahui beda rerata luas konversi lahan sawah sebelum dan setelah implementasi Perda Perlindungan Lahan Pertanian Pangan Berkelanjutan. Hasil Uji Wilcoxon variabel luas konversi lahan sawah di Jawa Barat

Tabel 2. Luas Konversi Lahan Sawah Sebelum dan Setelah Penerapan Perda LP2B

\begin{tabular}{lcc}
\hline \multirow{2}{*}{ Periode Tahun } & $\begin{array}{r}\text { Konversi Lahan Sawah } \\
\text { Sebelum Penerapan } \\
\text { Kebijakan (2004-2009) (ha) }\end{array}$ & $\begin{array}{r}\text { Konversi Lahan Sawah Setelah } \\
\text { Penerapan Kebijakan (2010-2015) (ha) }\end{array}$ \\
\hline $2004 / 2010$ & 0,00 & $7.105,00$ \\
$2005 / 2011$ & $6.437,00$ & 0,00 \\
$2006 / 2012$ & 0,00 & $6.932,00$ \\
$2007 / 2013$ & 0,00 & 0,00 \\
$2008 / 2014$ & 0,00 & 735,00 \\
$2009 / 2015$ & $8.171,00$ & $11.513,00$ \\
\hline Total & $14.608,00$ & $26.285,00$ \\
\hline Rerata & $2.434,67$ & $4.380,83$ \\
\hline
\end{tabular}

Sumber: BPS Jawa Barat, 2016 
sebelum dan setelah penerapan perda dapat dilihat pada tabel 3 berikut ini.

Tabel 3. Hasil Uji Wilcoxon Konversi Lahan Sawah Sebelum dan Setelah Implementasi Perda PLP2B

\begin{tabular}{lr}
\hline Keterangan & Setelah-Sebelum \\
\hline $\mathrm{Z}$ & $-1,214$
\end{tabular}

Asymp. Sig. (2-tailed) 0,225

Sumber: Analisis Data Sekunder, 2018

Berdasarkan tabel 3 dapat diketahui bahwa nilai signifikansi Uji Wilcoxon sebesar 0,225. Nilai tersebut lebih besar dari nilai alpha 5\%, sehingga $\mathrm{H} 0$ gagal ditolak yang berarti bahwa luas konversi lahan sawah sebelum dan setelah penerapan perda PLP2B di Jawa Barat secara statistik tidak memiliki perbedaan rerata yang signifikan. Oleh karena itu, hasil ini menunjukkan bahwa secara statistik penerapan perda belum memberikan dampak terhadap besar penurunan konversi lahan sawah di Jawa Barat. Meskipun secara statistik tidak terdapat perbedaan antara luas konversi lahan sawah yang terjadi sebelum dan setelah penerapan perda LP2B, tetapi dengan cara melakukan perhitungan langsung tetap teridentifikasi telah terjadi alih fungsi lahan yang cukup besar di Jawa Barat pada periode setelah perda tersebut disahkan. Hal ini akan berdampak pada produksi padi yang dapat dihasilkan di Jawa Barat. Data produksi padi di Jawa Barat sebelum dan setelah alih fungsi lahan sawah dapat dilihat pada tabel 4 berikut ini.

Berdasarkan tabel 4 dapat diketahui bahwa rerata produksi padi bruto di Jawa Timur sebelum penerapan perda LP2B adalah sebesar 11.549.271,00 ton per tahun dan rerata produksi padi bruto setelah penerapan perda adalah sebesar $13.365 .867,83$ ton per tahun. Hasil tersebut menunjukkan jumlah produksi padi bruto lebih besar pada periode setelah penerapan kebijakan perda. Secara umum, terjadinya konversi lahan sawah yang semakin besar dapat membawa dampak negatif terhadap menurunnya produksi padi bruto (Hidayat dkk., 2017; Millar \& Roots, 2012). Akan tetapi, hasil perhitungan pada tabel 4

Tabel 4. Produksi Padi Bruto Sebelum dan Setelah Penerapan Perda LP2B

\begin{tabular}{lcr}
\hline $\begin{array}{c}\text { Periode } \\
\text { Tahun }\end{array}$ & $\begin{array}{r}\text { Produksi Padi Bruto Sebelum } \\
\text { Penerapan Kebijakan (2004- } \\
\text { 2009) (ton) }\end{array}$ & $\begin{array}{r}\text { Produksi Padi Bruto Setelah } \\
\text { Penerapan Kebijakan (2010-2015) } \\
\text { (ton) }\end{array}$ \\
\hline $2004 / 2010$ & $11.004 .325,00$ & $13.187 .059,00$ \\
$2005 / 2011$ & $11.236 .530,00$ & $13.065 .098,00$ \\
$2006 / 2012$ & $11.170 .040,00$ & $12.523 .358,00$ \\
$2007 / 2013$ & $11.290 .037,00$ & $14.166 .770,00$ \\
$2008 / 2014$ & $11.929 .235,00$ & $13.690 .782,00$ \\
$2009 / 2015$ & $12.665 .459,00$ & $13.562 .140,00$ \\
\hline Total & $69.295 .626,00$ & $80.195 .207,00$ \\
\hline Rerata & $11.549 .271,00$ & $13.365 .867,83$ \\
\hline Sumber: BPS Jawa Barat, 2016 &
\end{tabular}


menunjukkan hal yang sebaliknya. Hal ini dapat terjadi dikarenakan semakin meningkatnya produktivitas lahan sawah di Jawa Barat yang didukung oleh kebijakan intensifikasi lahan sawah di Jawa Barat. Produktivitas padi yang semakin tinggi memberikan dampak positif terhadap meningkatnya produksi pada yang dihasilkan disuatu wilayah per satuan luas lahan sawah tersebut (Adrianto dkk., 2016; Wahed, 2015). Hasil produksi tersebut selanjutnya dapat di uji dengan Uji Wilcoxon untuk mengetahui ada tidaknya perbedaan yang nyata antara produksi yang dihasilkan sebelum dan setelah perda LP2B diterapkan. Hasil Uji Wilcoxon produksi padi bruto di Jawa Barat dapat dilihat pada tabel 5 berikut ini.

Tabel 5. Hasil Uji Wilcoxon Produksi Padi Bruto Sebelum dan Setelah Implementasi Perda PLP2B

\begin{tabular}{lr}
\hline Keterangan & $\begin{array}{r}\text { Setelah- } \\
\text { Sebelum }\end{array}$ \\
\hline $\mathrm{Z}$ & $-2,201$ \\
Asymp. Sig. (2-tailed) & 0,028 \\
\hline \multicolumn{2}{c}{ Sumber: Analisis Data Sekunder, 2018}
\end{tabular}

Berdasarkan tabel 5 dapat diketahui bahwa produksi padi bruto memiliki nilai signifikansi sebesar 0,028. Nilai tersebut lebih kecil dibandingkan dengan alpha 5\%, sehingga H0 dapat ditolak yang berarti bahwa terdapat perbedaan rerata jumlah produksi padi bruto yang signifikan antara sebelum dan sesudah penerapan perda LP2B. Pada periode setelah penerapan perda memiliki rerata produksi yang lebih tinggi dibandingkan sebelum penerapan perda, walaupun pada periode setelah penerapan perda memiliki nilai konversi lahan yang lebih besar dibandingkan dengan sebelum penerapan perda. Tingginya produksi ini terindikasi bukan disebabkan karena penerapan perda LP2B, tetapi akibat meningkatnya produktivitas padi pada periode tahun 2010 hingga 2011. Berdasarkan data Badan Pusat Statistik Provinsi Jawa Barat tahun 2016, rata-rata produktivitas padi pada periode tahun 2010-2015 mencapai angka 5,87 ton per hektar per tahun. Rata-rata produktivitas tersebut lebih tinggi dibandingkan dengan rata-rata produktivitas padi periode tahun 2004-2009 yang hanya mencapai angka 5,45 ton per hektar per tahun. Luas lahan terkonversi yang semakin tinggi tidak menjadi jaminan menurunnya produksi padi selama tingkat produktivitas padi juga meningkat, tetapi konversi lahan sawah menyebabkan hilangnya potensi produksi padi yang dapat dihasilkan (Prasada \& Rosa, 2018). Produksi padi bruto pada tabel 4 merupakan produksi padi kotor yang belum disesuikan dengan kebutuhan padi untuk benih, untuk pakan, padi tercecer, dan padi untuk industri non pangan (BKPP, 2016). Setelah produksi padi bruto dilakukan penyesuaian dengan faktor konversi padi bruto ke padi tersedia, maka dapat diketahui jumlah padi tersedia yang dapat diproses lebih lanjut menjadi beras. Produksi padi tersedia (netto) sebelum dan sesudah penerapan kebijakan lahan sawah di 
Tabel 6. Produksi Padi Netto Sebelum dan Setelah Penerapan Perda LP2B

\begin{tabular}{lrr}
\hline $\begin{array}{c}\text { Periode } \\
\text { Tahun }\end{array}$ & $\begin{array}{r}\text { Produksi Padi Netto Sebelum } \\
\text { Penerapan Kebijakan (2004- } \\
\text { 2009) (ton) }\end{array}$ & $\begin{array}{r}\text { Produksi Padi Netto Setelah } \\
\text { Penerapan Kebijakan (2010-2015) (ton) }\end{array}$ \\
\hline $2004 / 2010$ & $10.201 .009,28$ & $12.224 .403,69$ \\
$2005 / 2011$ & $10.416 .263,31$ & $12.111 .345,85$ \\
$2006 / 2012$ & $10.354 .627,08$ & $11.609 .152,87$ \\
$2007 / 2013$ & $10.465 .864,30$ & $13.132 .595,79$ \\
$2008 / 2014$ & $11.058 .400,85$ & $12.691 .354,91$ \\
$2009 / 2015$ & $11.740 .880,49$ & $12.572 .103,78$ \\
\hline Total & $64.237 .045,30$ & $74.340 .956,89$ \\
\hline Rerata & $10.706 .174,22$ & $12.390 .159,48$ \\
\hline
\end{tabular}

Sumber: BPS Jawa Barat, 2016

Jawa Barat dapat dilihat pada tabel 6 berikut ini.

Berdasarkan tabel 6 dapat diketahui bahwa produksi padi netto yang dihasilkan oleh Provinsi Jawa Barat sebelum penerapan perda LP2B rata-rata per tahun adalah sebesar 10.706.174,22 ton. Nilai tersebut jauh lebih kecil dibandingkan dengan rerata produksi padi netto Jawa Barat pada periode setelah penerapan perda yaitu sebesar 12.390.159,48 ton per tahun. Besarnya produksi beras netto di Jawa Barat pada periode setelah penerapan perda dapat disebabkan karena meningkatnya produktivitas lahan sawah. Data pada tabel 6 tidak dilakukan Uji Wilcoxon, sebab data pada tabel 6 merupakan data pada tabel 4 yang telah dilakukan penyesuaian dengan menggunakan faktor konversi padi bruto ke padi netto dari BKPP.

Data pada tabel 6 selanjutnya dapat dikonversikan kembali menjadi beras bruto dengan menggunakan faktor konversi padi ke beras yang disediakan oleh BKPP (2016).
Faktor konversi padi menjadi beras pada periode tahun 2004-2008 adalah sebesar 63,2\% dan periode tahun 2009-2015 adalah sebesar $62,7 \%$. Berdasarkan data faktor konversi yang digunakan oleh BKPP terjadi penurunan rendemen padi pada periode tahun tersebut. Hasil perhitungan produksi beras bruto di Jawa Barat sebelum dan setelah penerapan kebijakan LP2B dapat dilihat pada tabel 7 berikut ini.

Berdasarkan tabel 7 dapat diketahui bahwa rerata produksi beras bruto di Jawa Barat setelah penerapan perda LP2B jauh lebih tinggi dibandingkan pada periode waktu saat sebelum perda LP2B diterapkan. Sebelum pelaksanaan perda, produksi beras bruto di Jawa Barat rata-rata mencapai angka 6.756.518,04 ton per tahun. Nilai ini jauh lebih rendah dibandingkan dengan periode setelah perda diterapkan yang mencapai angka produksi beras bruto mencapai rata-rata sebesar 7.768.629,99 ton per tahun. Hal ini 
Tabel 7. Produksi Beras Bruto Sebelum dan Setelah Penerapan Perda LP2B

\begin{tabular}{lrr}
\hline $\begin{array}{c}\text { Periode } \\
\text { Tahun }\end{array}$ & $\begin{array}{r}\text { Produksi Beras Bruto } \\
\text { Sebelum Penerapan Kebijakan } \\
(2004-2009)(\text { ton })\end{array}$ & $\begin{array}{r}\text { Produksi Beras Bruto Setelah } \\
\text { Penerapan Kebijakan }(2010-2015) \\
\text { (ton) }\end{array}$ \\
\hline $2004 / 2010$ & $6.447 .037,86$ & $7.664 .701,12$ \\
$2005 / 2011$ & $6.583 .078,41$ & $7.593 .813,85$ \\
$2006 / 2012$ & $6.544 .124,31$ & $7.278 .938,85$ \\
$2007 / 2013$ & $6.614 .426,24$ & $8.234 .137,56$ \\
$2008 / 2014$ & $6.988 .909,33$ & $7.957 .479,53$ \\
$2009 / 2015$ & $7.361 .532,07$ & $7.882 .709,07$ \\
\hline Total & $40.539 .108,23$ & $46.611 .779,97$ \\
\hline Rerata & $6.756 .518,04$ & $7.768 .629,99$ \\
\hline
\end{tabular}

Sumber: BPS Jawa Barat, 2016

menunjukkan bahwa walaupun terjadi alih fungsi lahan sawah yang relative lebih besar pada periode setelah perda diterapkan, tetapi justru memiliki jumlah produksi beras bruto yang lebih besar. Fenomena ini dapat terjadi akibat meningkatnya produktivitas lahan sawah di Jawa Barat pada periode waktu se telah kebijakan perda LP2B diterapkan.

Data pada tabel 7 selanjutnya dapat dilakukan penyesuaian kembali dengan menggunakan faktor konversi beras bruto menjadi beras tersedia (netto) yang disediakan oleh BKPP (2016). Faktor konversi ini meliputi beras yang digunakan untuk pakan, beras tercecer, dan beras yang digunakan untuk industri non pangan. Hasil perhitungan beras tersedia sebelum dan setalah penerapan kebijakan perda LP2B dapat dilihat pada tabel 8 berikut ini.

Berdasarkan tabel 8 dapat diketahui bahwa rerata produksi beras netto pada periode sebelum penerapan perda adalah sebesar 6.531.525,99 ton per hektar. Jumlah produksi tersebut jauh lebih kecil dibandingkan dengan

Tabel 8. Produksi Beras Netto Sebelum dan Setelah Penerapan Perda LP2B

\begin{tabular}{lcc}
\hline $\begin{array}{c}\text { Periode } \\
\text { Tahun }\end{array}$ & $\begin{array}{r}\text { Produksi Beras Netto } \\
\text { Sebelum Penerapan Kebijakan } \\
(2004-2009)(\text { ton })\end{array}$ & $\begin{array}{r}\text { Produksi Beras Netto Setelah } \\
\text { Penerapan Kebijakan (2010-2015) (ton) }\end{array}$ \\
\hline $2004 / 2010$ & $6.232 .351,50$ & $7.409 .466,57$ \\
$2005 / 2011$ & $6.363 .861,90$ & $7.340 .939,84$ \\
$2006 / 2012$ & $6.326 .204,97$ & $7.036 .550,18$ \\
$2007 / 2013$ & $6.394 .165,84$ & $7.959 .940,78$ \\
$2008 / 2014$ & $6.756 .178,65$ & $7.692 .495,46$ \\
$2009 / 2015$ & $7.116 .393,05$ & $7.620 .214,86$ \\
\hline Total & $39.189 .155,92$ & $45.059 .607,70$ \\
\hline Rerata & $6.531 .525,99$ & $7.509 .934,62$ \\
\hline
\end{tabular}

Sumber: BPS Jawa Barat, 2016 
produksi beras netto pada periode setelah perda LP2B diterapkan di Jawa Barat, yaitu rata-rata sebesar 7.509.934,62 ton per hektar. Hal ini dapat terjadi disebabkan oleh meningkatnya produktivitas lahan sawah di Jawa Barat pada beberapa tahun terakhir, sehingga produksi beras netto juga meningkat.

Terjadinya konversi lahan sawah di Jawa Barat tidak hanya memberikan dampak terhadap perubahan produksi beras yang dapat dihasilkan, melainkan juga dapat memberikan dampak terhadap tingkat pemenuhan kebutuhan pangan penduduk. Penduduk yang mampu terpenuhi seluruh kebutuhan pangannya, dapat dikategorikan dalam kategori tahan pangan, sebaliknya saat kebutuhan pangan penduduk tidak dapat terpenuhi dengan baik, maka dapat menurunkan tingkat ketahanan pangan. Jumlah penduduk yang semakin meningkat dari tahun ke tahun menjadi tantangan besar bagi sektor pertanian untuk dapat memenuhi seluruh kebutuhan pangan penduduk tersebut ditengah terjadinya alih fungsi lahan sawah yang relative besar di Jawa Barat. Tingkat ketahanan pangan penduduk di Jawa Barat sebelum dan setelah implementasi kebijakan perda LP2B dapat dilihat pada tabel 9 berikut ini.

Berdasarkan data pada tebel 9 dapat diketahui bahwa tingkat ketahanan pangan sebelum penerapan perda LP2B rata-rata adalah sebesar $166,01 \%$. Nilai tersebut lebih besar dari 100\% menunjukkan pada periode sebelum penerapan perda terjadi surplus beras, yaitu suatu kondisi jumlah beras tersedia lebih besar dibandingkan dengan jumlah kebutuhan beras. Pada periode setelah kebijakan LP2B diterapkan, surplus beras yang terjadi lebih besar mencapai angka 84,04\% per tahun. Hasil tersebut memberikan gambaran bahwa pada periode setelah penerapan kebijakan LP2B, ketahanan pangan penduduk menjadi lebih baik, walaupun alih fungsi lahan terjadi

Tabel 9. Ketahanan Pangan Penduduk Jawa Barat Sebelum dan Setelah Penerapan Perda LP2B

\begin{tabular}{lcc}
\hline $\begin{array}{c}\text { Periode } \\
\text { Tahun }\end{array}$ & $\begin{array}{c}\text { Ketahanan Pangan Sebelum } \\
\text { Penerapan Kebijakan (2004- } \\
\text { 2009) }(\%)\end{array}$ & $\begin{array}{c}\text { Ketahanan Pangan Setelah } \\
\text { Penerapan Kebijakan (2010-2015) (\%) }\end{array}$ \\
\hline $2004 / 2010$ & 125,68 & 171,15 \\
$2005 / 2011$ & 143,92 & 205,31 \\
$2006 / 2012$ & 218,47 & 173,82 \\
$2007 / 2013$ & 172,15 & 188,31 \\
$2008 / 2014$ & 164,60 & 190,76 \\
$2009 / 2015$ & 171,25 & 174,96 \\
\hline Total & 996,07 & 1104,31 \\
\hline Rerata & 166,01 & 184,05 \\
\hline
\end{tabular}

Sumber: BPS Jawa Barat, 2016 
relative besar pada periode yang sama dan jumlah penduduk semakin meningkat dari tahun ke tahun. Hal tersebut terindikasi bukan disebabkan karena penerapan perda, tetapi akibat produksi beras netto yang lebih tinggi pada periode setelah penerapan kebijakan perda LP2B dan relative menurunnya tingkat konsumsi beras per kapita penduduk di Jawa Barat (BPS, 2016). Selanjutnya untuk mengetahui ada tidaknya perbedaan yang signifikan antara ketahanan pangan sebelum dan setelah penerapan kebijakan LP2B dilakukan Uji Wilcoxon. Hasil Uji Wilcoxon pada tingkat ketahanan pangan penduduk sebelum dan setelah penerapan perda LP2B dapat dilihat pada tabel 10 berikut ini.

Tabel 10. Hasil Uji Wilcoxon Ketahanan Pangan Sebelum dan Setelah Implementasi Perda PLP2B

\begin{tabular}{lr}
\hline Keterangan & \multicolumn{1}{c}{ Setelah-Sebelum } \\
\hline $\mathrm{Z}$ & $-1,363$
\end{tabular}

Asymp. Sig. (2-tailed) $\quad 0,173$

Sumber: Analisis Data Sekunder, 2018

Berdasarkan hasil Uji Wilcoxon dapat diketahui bahwa nilai signifikansi sebesar 0,173 . Nilai tersebut lebih besar dibandingkan dengan nilai alpha 5\%, sehingga H0 gagal ditolak dan berarti bahwa tidak ada perbedaan rerata yang nyata antara rerata tingkat ketahanan pangan penduduk di Jawa Barat sebelum dan setelah implementasi perda LP2B. Hasil tersebut menunjukkan penerapan perda LP2B yang telah dilakukan hingga saat ini belum memberikan dampak positif ataupun dampak negatif yang signifikan secara statistik terhadap ketahanan pangan penduduk.

\section{KESIMPULAN DAN SARAN}

\section{KESIMPULAN}

Peraturan Daerah Provinsi Jawa Barat Nomor 27 Tahun 2010 Tentang Perlindungan Lahan Pertanian Pangan Berkelanjutan seyogyanya dirumuskan, dibentuk, dan disahkan dengan semangat untuk mencegah dan mengendalikan laju alih fungsi lahan sawah di Jawa Barat. Akan tetapi, pada implementasinya peraturan ini belum dapat dijalankan dengan baik akibat terjadinya ketidakefektifan pelaksanaan perda tersebut. Hal ini dapat terlihat dari rerata luas lahan sawah terkonversi yang justru lebih besar pada periode setelah perda disahkan.

\section{SARAN}

Ketidakefektifan dalam implementasi Peraturan Daerah Provinsi Jawa Barat Nomor 27 Tahun 2010 Tentang Perlindungan Lahan Pertanian Pangan Berkelanjutan perlu segera diatasi dengan baik untuk memastikan agar lahan sawah di wilayah tersebut terlindungi dan berkelanjutan. Upaya yang dapat dilakukan untuk mengatasi ketidakefektifan implementasi perda tersebut antara lain memberikan kejelasan terkait objek lahan pertanian yang akan dilindungi, sehingga masyarakat dan stakeholder memiliki acuan yang sama terkait lahan pertanian mana yang tidak boleh dialihfungsikan dan lahan 
pertanian mana yang dapat dialihfungsikan.

Selain itu, sangat diperlukan sosialisasi dan edukasi kepada masyarakat terkait pentingnya melindungi lahan pertanian pangan. Hal ini diharapkan dapat meningkatkan pengetahuan dan kesadaran masyarakat tentang pentingnya perlindungan lahan pertanian pangan.

\section{UCAPAN TERIMAKASIH}

Terima kasih penulis ucapkan kepada Lembaga Pengelola Dana Pendidikan (LPDP) yang telah memberikan support dana untuk kegiatan penelitian dan publikasi yang penulis lakukan.

\section{DAFTAR PUSTAKA}

BPS Provinsi Jawa Barat. (2016). Daerah dalam angka 2016. Badan Pusat Statistik Provinsi Jawa Barat. Jawa Barat.

BKPP. (2016). Neraca Bahan Makanan (NBM). Badan Ketahanan Pangan dan Penyuluhan. Jakarta.

Adrianto, J., Harianto, \& Hutagaol, P. (2016). Peningkatan produksi padi melalui penerapan SRI (System of Rice Intensification) di Kabupaten Solok Selatan. Jurnal Agribisnis Indonesia, 4(2), 107-122. Retrieved from http://journal.ipb.ac.id/index.php/jagbi/a rticle/viewFile/17126/12411

Anita, M. F., Bambang, A. N., \& Purnaweni, H. (2012). Analisis Prioritas Kebijakan Perlindungan Lahan Pertanian Pangan Berkelanjutan di Kabupaten Magelang. Jurnal EKOSAINS, IV(3), 20-26.

Aragie, T., \& Genanu, S. (2017). Level and determinants of food security in North Wollo Zone (Amhara Region-Ethiopia). Journal of Food Security, 5(6), 232-247. https://doi.org/10.12691/jfs-5-6-4

Darsono. (2012). Faktor Utama Swasembada
Pangan Tingkat Rumah Tangga Petani Lahan Kering di Kabupaten Wonogiri Provinsi Jawa Tengah. SEPA, 9(1), 100116.

Daulay, A. R., P, E. I. K., Barus, B., \& Bambang, P. N. (2016). The Acceptable Incentive Value To Succeed Paddy Land Protection Program in Regency of East Tanjung Jabung, Indonesia. ARPN Journal of Agricultural And Biological Science, 11(8), 307-312.

Dwipradnyana, I. M. M., Windia, W., \& Sudarma, I. M. (2015). Faktor-faktor yang mempengaruhi konversi lahan serta dampaknya terhadap kesejahteraan petani: Kasus Subak Jadi, Kecamatan Kediri, Kabupaten Tabanan. Jurnal Manajemen Agribisnis, 3(1), 34-42.

Hadiwinata, K., Sudarsono, Isrok, \& Ridwan, M. (2014). Legal Politics of License Regulation in the Conversion of Agricultural Soil to Non-Agricultural in the Era of Regional Autonomy. Academic Research International, 5(4), 494-502.

Hidayat, Y., Ismail, A., \& Ekayani, M. (2017). Rumah tangga petani padi ( Studi Kasus Kecamatan Kertajati Kabupaten Majalengka Jawa Barat ). Jurnal Pengkajian Dan Pengembangan Teknologi Pertanian, 20(2), 171-182.

Irawan, A. (2014). Implementasi kebijakan pengendalian alih fungsi lahan pertanian pangan berkelanjutan di Kecamatan Rimba Melintang Kabupaten Rokan Hilir. JOM FISIP, 1(2), 1-14.

Keiky, Y. R. (2016). Instrumen Kebijakan Perlindungan Lahan Pertanian Pangan Berkelanjutan (Studi Proses Perumusan dan Analisis Karakteristik Instrumen Kebijakan Perlindungan Lahan Pertanian Pangan Berkelanjutan di Kabupaten Bojonegoro). Kebijakan Dan Manajemen Publik, 4(2), 116-125.

Millar, J., \& Roots, J. (2012). Changes in Australian agriculture and land use: Implications for future food security. International Journal of Agricultural Sustainability, 10(1), 25-39. https://doi.org/10.1080/14735903.2012. 
646731

Mulyani, A., Ritung, S., \& Las, I. (2011). Potensi dan ketersediaan sumber daya lahan untuk mendukung ketahanan pangan. Jurnal Litbang Pertanian, 30(12), 73-80.

Prasada, I. M. Y., \& Rosa, T. A. (2018). Dampak alih fungsi lahan sawah terhadap ketahanan pangan di Daerah Istimewa Yogyakarta. Jurnal Sosial Ekonomi Pertanian, 14(1), 180-194.

Provinsi Jawa Barat. 2010. Peraturan Daerah Provinsi Jawa Barat Nomor 27 Tahun 2010 Tentang Perlindungan Lahan Pertanian Pangan Berkelanjutan. Lembaran Daerah Provinsi Jawa Barat Tahun 2010 Nomor 27 Seri E. Sekretaris Daerah Provinsi Jawa Barat. Bandung.

Purbiyanti, E., Yazid, M., \& Januarti, I. (2017). Konversi lahan sawah di Indonesia dan pengaruhnya terhadap kebijakan Harga Pembelian Pemerintah ( HPP ) gabah/beras. Jurnal Manajemen \& Agribisnis, 14(3), 209-217.

Purwaningsih, Y., Istiqomah, N., \& Sutomo, S. (2015). Analisis Dampak Alih Fungsi Lahan terhadap Tingkat Ketahanan Pangan Rumah Tangga Petani di Kabupaten Karanganyar Provinsi Jawa Tengah. AGRARIS: Journal of Agribusiness and Rural Development Research, 1(2), 98-107. https://doi.org/10.18196/agr.1213

Rachmanto, Y. (2014). Efektivitas pelaksanaan perlindungan lahan pertanian dari alih fungsi menjadi lahan non pertanian di Kabupaten Kediri. Jurnal Ilmiah Universitas Brawijaya, 2014(1), 1-18.

Republik Indonesia. 2009. Undang-Undang Nomor 41 Tahun 2009 Tentang Perlindungan Lahan Pertanian Pangan Berkelanjutan. Lembaran Negara Republik Indonesia Tahun 2009 Nomor
149. Tambahan Lembaran Negara Republik Indonesia Nomor 5068. Kementerian Hukum dan Hak Asasi Manusia RI. Jakarta.

Santosa, I. G. N., Menaka Adnyana, G., \& Dinata, I. K. K. (2011). Dampak Alih Fungsi Lahan Sawah Terhadap Ketahanan Pangan Beras. Prosiding Seminar Nasional Budidaya Pertanian, 2011(Juli), 1-11.

Suandi. (2012). Modal sosial dan pembangunan ketahanan pangan sustainable food security development and social. AGRISEP, 11(2), 270-281.

Tanty, H., Bekti, R. D., \& Rahayu, A. (2013). Metode Nonparametrik Untuk Analissi Hubungan Perilaku dan Pengerahuan Masyarakat Tentang Kode Plastik. Mat Stat, 13(2), 97-104.

Wahed, M. (2015). Pengaruh Luas Lahan, Produksi, Ketahanan Pangan dan Harga Gabah Terhadap Kesejahteraan Petani Padi di Kabupaten Pasuruan. Jesp, 7(1), 68-74.

Wang, J., Lin, Y., Glendinning, A., \& Xu, Y. (2018). Land-use changes and land policies evolution in China's urbanization processes. Land Use Policy, 75(October 2015), 375-387. https://doi.org/10.1016/j.landusepol.201 8.04.011

Yanti, R. T., Ridwan, M., \& Rospida, L. (2013). Analisis alih fungsi lahan pertanian tanaman pangan padi sawah ke sektor perkebunan kelapa sawit dan karet serta pengaruhnya terhadap produksi padi di Kabupaten Seluma Provinsi Bengkulu. Jurnal Ekonomi Dan Perencanaan Pembangunan, 5(2), 6475.

Yasar, M., \& Siwar, C. (2016). Paddy Field Conversion in Malaysia: Issues and Challenges. Rona Teknik Pertanian, 9(2), 168-177. 